\title{
Expression of genes encoding the pre-TCR and CD3 complex during thymus development
}

\author{
Anne Wilson and $\mathbf{H}$. Robson MacDonald \\ Ludwig Institute for Cancer Research, Lausanne Branch, University of Lausanne, 1066 Epalinges, \\ Switzerland
}

Keywords: development, T cell, thymus

\begin{abstract}
The mature TCR is composed of a clonotypic heterodimer ( $\alpha \beta$ or $\gamma \delta$ ) associated with the Invarlant CD3 components $(\gamma, \delta, \varepsilon$ and $\zeta)$. There is now considerable evidence that more immature forms of the TCR-CD3 complex (consisting of either CD3 alone or CD3 assoclated with a heterodimer of TCR $\beta$ and pre-T $\alpha$ ) can be expressed at the cell surface on early thymocytes. These pre-TCR complexes are believed to be necessary for the ordered progresslon of early $T$ cell development. We have analyzed In detail the expression of both the pre-TCR and CD3 complex at various stages of adult thymus development. Our data indicate that all CD3 components are already expressed at the mRNA level by the earliest identifiable (CD4 ${ }^{\text {lo }}$ ) thymic precursor. In contrast, genes encoding the pre-TCR complex (pre-T $\alpha$ and fully rearranged TCR $\beta$ ) are flrst expressed at the $\mathrm{CD}_{4}{ }^{\circ} \mathrm{CD} 25^{+} \mathrm{CD}^{-} \mathrm{CD} 8^{-}$stage. Detectable surface expression of both CD3 and TCR $\beta$ are delayed relative to expression of the corresponding genes, suggesting the existence of other (as yet unidentifled) components of the pre-TCR complex.
\end{abstract}

\section{Introduction}

The TCR is a complex, multisubunit structure that consists of at least six chains ( $\alpha$ and $\beta$, or $\gamma$ and $\delta$, as well as the CD3 $\gamma$, $\delta, \varepsilon$ and $\zeta$ chains) that are assembled in the endoplasmic reticulum and transported to the cell surface (reviewed in $1-5)$. Whereas the $\alpha, \beta, \gamma$ and $\delta$ chains of the TCR are clonotypic and confer ligand specificity, the CD3 subunits are Invariant and function as signal transducing molecules through interactions of their cytoplasmic domains with the protein tyrosıne kinases ZAP-70 or $p 56^{\text {lck }}(6-8)$

Efficient surface expression of a functional TCR-CD3 complex on mature $T$ cells has been shown to require all six chains (9). In the absence of either TCR $\alpha$ or TCR $\beta(10,11)$, mature T cells bearing functional TCR $\alpha \beta-C D 3$ complexes do not develop. In mice deficient for CD3 $\zeta$ (12-15), a similar absence of mature, functional $\alpha \beta$ T cells is observed. While it is generally accepted that surface expression of a functional CD3-TCR complex occurs uniquely on mature T cells, several lines of evidence suggest that low levels of CD3 may be expressed on the surface of immature thymocytes either alone or in association with TCR $\beta$. Thymocyte development in TCR $\alpha^{+-}$mice is arrested at the CD4 ${ }^{+} \mathrm{CD} 8^{+}$double-positive (DP) stage $(10,11)$. While no TCR $\alpha \beta$ heterodimer is expressed, low levels of $\mathrm{CD} 3$ and TCR $\beta$ can be detected on these DP cells by FACS analysis. Furthermore, low levels of $\mathrm{CD} 3$ $\varepsilon$ protein have been detected at even earlier stages of development, both intracellularly in $\mathrm{CD} 44^{\text {to }} \mathrm{CD} 25^{+}$doublenegative (DN) thymocytes (16) and on the surface of CD44 ${ }^{\circ} \mathrm{CD} 25^{-}$DN thymocytes $(17,18)$. In addition, studies in the normal human thymus (19) and in acute lymphoblastic leukemias $(20,21)$ have also demonstrated the presence of CD3 $\varepsilon$ protein in immature $T$ cells, although the exact stage of development was not determined. Finally, biochemical studies have shown that CD3 $\varepsilon, \gamma$ and $\delta$ (in the presence or absence of TCR $\beta$ chains), may be detected on the surface of SCID thymocytes (22), SCID cell lines (23) and RAG$1^{\text {t- }}$ thymocytes (24), all of which are principally of the $\mathrm{CD} 44^{10} \mathrm{CD} 25^{+} \mathrm{DN}$ phenotype.

While the exact composition of this immature CD3 complex is not known, it has been shown that signals can be transduced in immature thymocytes by its ligation. Treatment of $\mathrm{RAG}^{-1}$ thymocytes with anti-CD3e mAb, either in vivo $(24,25)$ or in vitro (26), induces expansion and differentiation of $\mathrm{CD} 44^{10} \mathrm{CD} 25^{+} \mathrm{DN}$ cells to the DP stage in the absence of TCR rearrangement. $\mathrm{RAG}^{-1}$ or SCID thymocytes can also be 
induced to expand and differentiate to the DP stage under the influence of either a TCR $\beta$ transgene $(24,27,28)$ or a p56 lck transgene (29). Taken together, these results in both normal and mutant mice provide strong evidence for the presence of at least some components of the TCR-CD3 complex on immature thymocytes.

A pre-TCR complex, consisting of a rearranged TCR $\beta$ chain and the recently cloned $p T \alpha$ chain (30), associated with the CD3 complex has recently been described (23). pT $\alpha$, which is believed to be a key component of the pre-TCR, is expressed in immature DN and DP thymocytes of TCR $\alpha^{-1-}$ and $\mathrm{RAG}-2^{-1}$ mice and not on mature $T$ cells. In this study we have investigated in detail the expression of the genes encoding the pre-TCR and CD3 complex during early adult thymus development.

\section{Methods}

Mice and thymocyte subsets

Normal C57BI/6 female mice were purchased from Harlan/ Olac (Bicester, UK) and used at 4-6 weeks of age. Thymocyte subsets were purified by complement-mediated cytotoxicity and magnetic bead depletion $(31,32)$, and further sorted on a FACStar Plus (Becton Dickinson, Mountain View, CA).

\section{Northern blot analysis and in situ hybridization}

Total cell RNA was prepared by $\mathrm{CsCl}_{2}$ gradient, electrophoresed on formaldehyde-agarose minigels and hybridized with RNA probes as described previously (31). In situ hybridization was performed on single cells FACS-sorted directly onto microscope slides (31). The probes used were as follows: TCR $\mathrm{C}_{\beta} 2$ and $\beta$-actin (31); CD3 $\varepsilon$, a 1200 bp Xbal-BamH insert in pBS.KSII; CD3 $\gamma$, a 700 bp ECORI-HindlII insert in pBS.KSIl; CD3 $\delta$, a 800 bp Xhol insert in pBS.KSII; CD3 $\zeta$, a 1100 bp EcoRl insert in pBS.SK (these latter four probes were the kind gift of Bernard and Marie Malissen, Marseille-Luminy, France); and pT $\alpha$ which is a 660 bp insert in Bluescript $\mathrm{KS}^{+}$made by PCR amplification of CDNA from $\mathrm{CD}_{2} 5^{+} \mathrm{DN}$ thymocytes using the published primer sequences (30). All probes were labeled by RNA transcription with either [ $\alpha$ ${ }^{32}$ P]UTP (for Northern blot) or [ $\alpha{ }^{35}$ S] UTP (for in situ). P815 mastocytoma cells were used as a negative control for in situ hybridization. According to the criteria used, $\sim 2-3 \%$ cells were positive by in situ hybridization for each of the CD3 probes. Densitometry readings of the exposed $X$-ray films was performed with the Elscript 400 densitometer (HirschmannGetaebau, Unterhachingen, Germany) and the results analyzed with the accompanying software.

\section{FACS analysis}

Four-color FACS analysis was performed on a FACStar Plus equipped with a standard argon laser (for FITC, PE and Red-613 in FL1, 2 and 3), and a helium-neon laser for allophycocyanin (APC) (FL4). Fluorescent conjugates were as follows: APC-streptavidin (Molecular Probes, Eugene, OR); control hamster Ig-PE, PE-streptavidin and anti-CD4-APC (Caltag, South San Francisco, CA); anti-CD3-PE, anti-CD4Red-613, anti-CD8-Red-613 and anti-CD25-Red-613 (Gibco/ BRL, Gaithersberg, MD); anti-TCRß-PE and HSA-PE (PharM-
Ingen, San Diego, CA); anti-CD44-FITC, antı-HSA-bıtin and anti-CD25-biotın were prepared in this laboratory.

\section{Results}

\section{CD3 mRNA expression by immature thymus subsets}

During adult thymus development, immature T cells of the $\alpha \beta$ lineage follow a complex developmental program in which differentiation is accompanied by TCR gene rearrangement and expression. The earliest identifiable thymocyte expresses low levels of CD4 (but not CD8 or CD3) and has its TCR genes in germline configuration (33) CD4 is down-regulated and the cells progress through a series of DN (CD4-CD8 ${ }^{-}$) subsets characterized by the differential expression of CD44 and CD25 in the order: CD44 ${ }^{\text {hi }} \mathrm{CD} 25^{-}$to $\mathrm{CD} 44^{\text {hi }} \mathrm{CD} 25^{+}$to $\mathrm{CD} 44^{\circ} \mathrm{CD} 25^{+}$to $\mathrm{CD} 44^{\circ} \mathrm{CD} 25^{-}(34-39)$ Transition from the late $\mathrm{DN}\left(\mathrm{CD} 4^{-} \mathrm{CD} 8^{-}\right)$to the $\mathrm{DP}\left(\mathrm{CD} 4^{+} \mathrm{CD8^{+ }}\right)$ stage can occur via an immature single positive (ISP) and is accompanied by expansion (reviewed in 40). Later stages of thymus development involve repertoire selection, up-regulation of a mature TCR-CD3 complex and production of mature single-positive (SP) $\mathrm{CD}^{+}$or $\mathrm{CD}^{+}$cells $(41-43)$.

In order to determine at which stage of $T$ cell development in the adult thymus $\operatorname{CD} 3 \varepsilon, \gamma, \delta$ and $\zeta$ genes are first expressed, we performed in situ hybridization studies at the single cell level on thymus subsets. As shown in Table 1, a substantial proportion (53-90\%) of celis in the earliest identifiable thymocyte population (the $\mathrm{CD} 4^{\text {lo }}$ precursor), were positive for each of the CD3 genes. The percent positive cells expressing each of these genes increased gradually in subsequent populations to reach essentially $100 \%$ in the CD $44^{10} \mathrm{CD} 25^{+}$DN subset and remained stable throughout further stages of thymus development as well as in mature T cells.

As virtually all cells from the CD $44^{\mathrm{lo}} \mathrm{CD} 25^{+} \mathrm{DN}$ subset onwards were positive for $\operatorname{CD} 3 \varepsilon, \gamma, \delta$ and $\zeta$ chain mRNA, it was interesting to examine whether the level of expression was similar in each subset. To this end, Northern blot analysis was performed on total RNA prepared from purified thymocyte subsets commencing at the $\mathrm{CD} 44^{\mathrm{l}} \mathrm{CD} 25^{+} \mathrm{DN}$ stage. As shown in Fig. 1 and Table 2, CD3 $\varepsilon$ and $\mathrm{CD} 3 \delta$ were expressed in approximately equivalent amounts in all subsets. By contrast, CD3 $\gamma$ was expressed at higher levels in the $\mathrm{CD} 44^{10} \mathrm{CD} 25^{+} \mathrm{DN}$ than in the later immature $\left(\mathrm{CD} 44^{10} \mathrm{CD} 25^{-}\right.$

Table 1. CD3 gene expression in immature thymocyte subsets

\begin{tabular}{|c|c|c|c|c|}
\hline \multirow{2}{*}{$\begin{array}{l}\text { Thymocyte } \\
\text { subset }^{\mathrm{e}}\end{array}$} & \multicolumn{4}{|c|}{ Cells positive $(\%)^{\mathrm{b}}$} \\
\hline & $\mathrm{CD} 3 \varepsilon$ & $\mathrm{CD} 3 \gamma$ & CD38 & CD35 \\
\hline 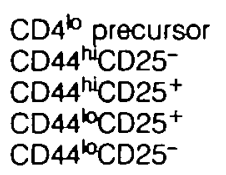 & $\begin{array}{l}80 \pm 5 \\
90 \pm 7 \\
91 \pm 3 \\
100 \\
100\end{array}$ & $\begin{array}{l}88 \pm 9 \\
97 \pm 3 \\
97 \pm 5 \\
99 \pm 4 \\
100\end{array}$ & $\begin{array}{l}53 \pm 10 \\
64 \pm 7 \\
89 \pm 3 \\
98 \pm 3 \\
100\end{array}$ & $\begin{array}{l}69 \pm 6 \\
82 \pm 8 \\
97 \pm 3 \\
100 \\
100\end{array}$ \\
\hline
\end{tabular}

${ }^{a}$ All more mature subsets and mature T cells were $\sim 100 \%$ positive. bFor each probe 500-1000 cells were counted on each slide and two to four separate slides analyzed. 
DN, ISP, DP) and more mature (SP and lymph node $T$ cells) subsets. The levels of CD3 $\zeta$ mRNA expression, while substantially lower than those of $\mathrm{CD} 3 \varepsilon, \gamma$ and $\delta$, also varied considerably during development. Maximum expression of $\zeta$ was observed at the DP stage, much later than the peak expression of $\operatorname{CD} 3 \gamma$ The maximum levels of expression of

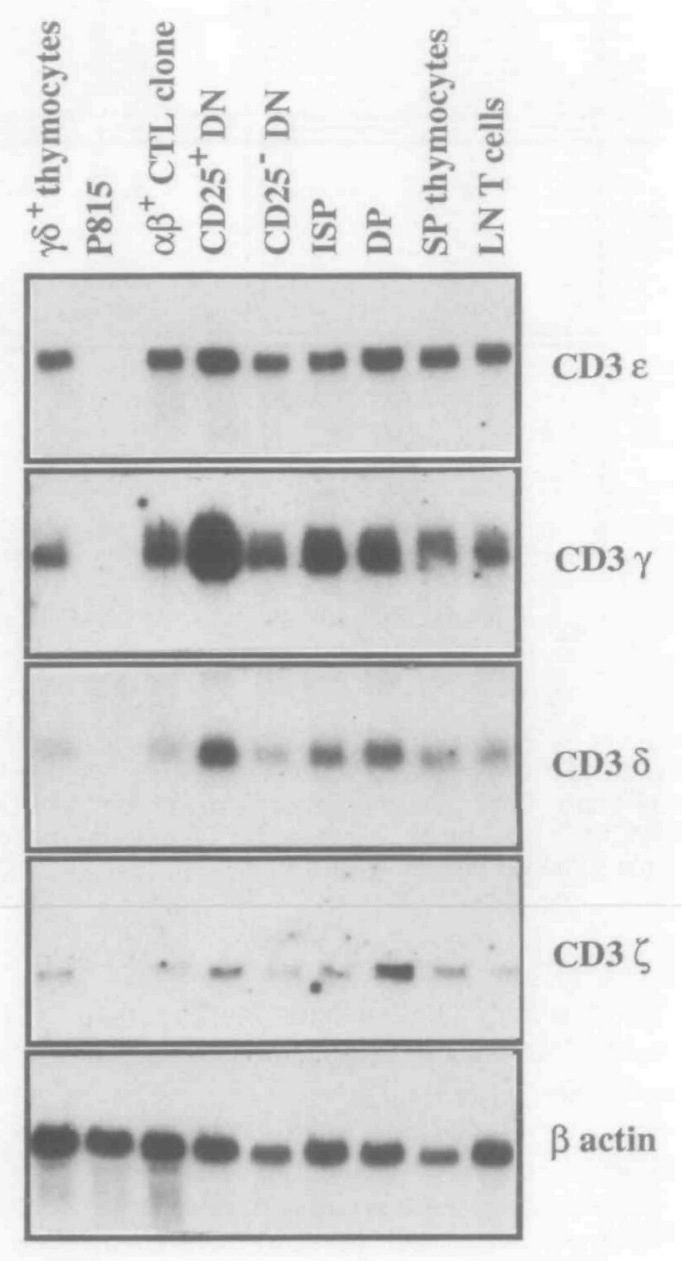

Fig. 1. Expression of CD3 genes in thymocyte subsets by Northern blot analysis. Sequential hybridizations of the same blot were performed with probes for $\operatorname{CD} 3 \varepsilon, \gamma, \delta, \zeta$ and $\beta$-actin. Control cells were polyclonally activated $\gamma \delta$ thymocytes, P815 mastocytoma and $\alpha \beta$ CTL clone. Exposure times were overnight for all probes
CD3 $\gamma$ at the CD $44^{\text {lo }} \mathrm{CD} 25^{+} \mathrm{DN}$ stage, coupled with the fact that virtually all cells at this stage express mRNA from all genes of the CD3 complex, is consistent with the possibulity of surface CD3 expression as suggested by both biochemical and functional studies $(16,22-24)$.

\section{Expression of $p T \alpha$ and TCR $\beta$ mRNA in immature thymocytes}

The recently identified pT $\alpha$ chain has been shown to be expressed as a heterodimer with TCR $\beta$ as part of the CD3associated pre-TCR complex $(23,30)$. In order to determine at which stage during T cell development TCR $\beta$ and $\mathrm{pT} \alpha$ are first expressed, we performed Northern blot analysis of early thymus subsets As shown in Fig. 2, pT $\alpha$ is first detected in $\mathrm{CD} 44^{\mathrm{l}} \mathrm{CD} 25^{+} \mathrm{DN}$ cells and not in earlier subsets Expression continues through to the DP stage, but no pT $\alpha$ mRNA is detected in either mature SP thymocytes (Fig. 2) or lymph node $T$ cells (data not shown). These results are consistent with those obtained recently by PCR analysis (30). Full length (VDJC) TCR $\beta$ transcripts are also first detected at the $\mathrm{CD} 44^{\circ} \mathrm{CD} 25^{+} \mathrm{DN}$ stage, although both truncated (DJC) and longer (presumably germline) transcripts are detected earlier in the CD44 h'CD25 ${ }^{+}$subset (Fig. 2). Taken together with the CD3 data, these results are consistent with the potential expression of a pre-TCR-CD3 complex by immature thymocytes beginning at the $\mathrm{CD} 44^{\circ} \mathrm{CD} 25^{+} \mathrm{DN}$ stage.

\section{Surface expression of CD3 $\mathbf{\varepsilon}$ and TCR $\beta$ on immature thymocytes}

Although high levels of $\mathrm{CD} 3 \varepsilon, \gamma, \delta$ and $\zeta$ mRNA are expressed through all stages of thymocyte development (Fig. 1 and Tables 1 and 2), and full length TCR $\beta$ transcripts are produced at the $\mathrm{CD} 44^{\text {lo }} \mathrm{CD} 25^{+}$DN stage $(31,35$ and Fig. 2), a mature CD3-TCR $\alpha \beta$ complex is not expressed on the surface of Immature thymocytes due to the absence of TCR $\alpha$ chains However, intracellular CD3 $\varepsilon$ protein can be detected in $\mathrm{CD} 44^{10} \mathrm{CD} 25^{+} \mathrm{DN}$ thymocytes (data not shown and 16 ) and evidence described above suggests that a functional CD3 complex may be expressed, albeit at low levels, on this subset We therefore decided to determine at what stage of development $\operatorname{CD} 3 \varepsilon$ and TCR $\beta$ could be detected at the cell surface.

To this end, four-color FACS analysis was performed on thymocyte subsets from the $\mathrm{CD} 44^{\mathrm{lo}} \mathrm{CD} 25^{+} \mathrm{DN}$ through to mature SP stages. As shown in Fig. 3, neither CD3 $\varepsilon$ nor TCR $\beta$ are detectable in the $\mathrm{CD} 44^{\circ} \mathrm{CD} 25^{+} \mathrm{DN}$ subset; however, surface CD3 $\varepsilon$ and TCR $\beta$ are detectable in the CD44 ${ }^{\circ} \mathrm{CD} 25^{-}$ DN stage. These results are consistent with the expression

Table 2. Quantitation of CD3 gene expression in thymocyte subsets

\begin{tabular}{|c|c|c|c|c|c|c|c|c|c|}
\hline Probe & $\gamma^{+}$thymocytes & P815 & $\begin{array}{l}\alpha \beta^{+} \text {CTL } \\
\text { clone }\end{array}$ & $\mathrm{CD}_{25} 5^{+} \mathrm{DN}$ & $\mathrm{CD} 25^{-} \mathrm{DN}$ & ISP & DP & $\mathrm{SP}$ & Lymph $\operatorname{nod} \theta T$ \\
\hline CD3e & 1.1 & 0 & 1.1 & 3.2 & 1.6 & 1.0 & 2.3 & 25 & 1.0 \\
\hline $\mathrm{CD} 3 \gamma$ & 1.2 & 0 & 0.9 & 18.1 & 2.8 & 32 & 2.3 & 2.7 & 1.0 \\
\hline $\mathrm{CD} 3 \delta$ & 0.9 & 0 & 0.7 & 3.0 & 13 & 18 & 27 & 2.3 & 1.0 \\
\hline $\mathrm{CD} 3 \zeta$ & 1.0 & 0 & 1.2 & 2.3 & 2.0 & 1.8 & 6.6 & 4.0 & 1.0 \\
\hline
\end{tabular}

Densitometry was performed on the autoradiographs in Fig. 1. For each subset densitometric values were divided by the $\beta$-actin control. Data for each of the $\mathrm{CD} 3$ probes are arbitrarily normalized to a value of 1.0 for lymph node $\mathrm{T}$ cells. 


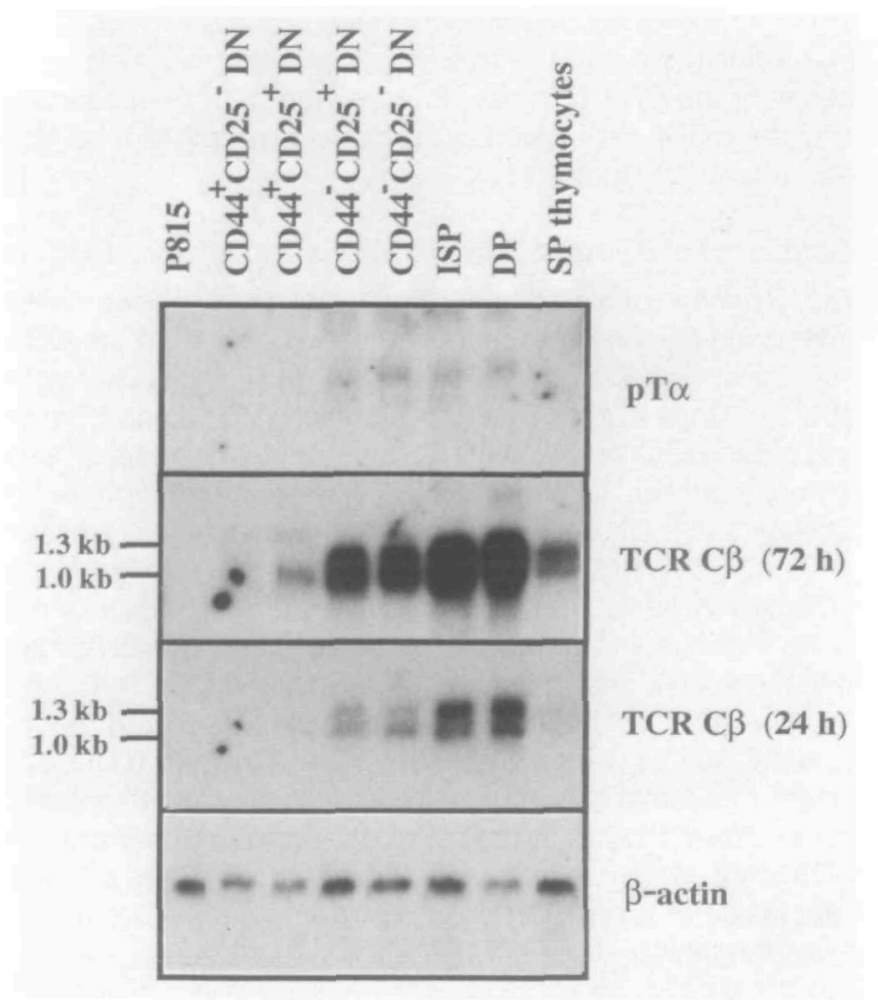

Fig. 2. Expression of TCR $\beta$ and $p$ T $\alpha$ in thymocyte subsets. Thymocyte subsets and control cells are as in Fig 1, with the addition of the two earlier CD44 ${ }^{\text {hl }}$ DN subsets. The blot was hybridized sequentially with TCR $C_{\beta}, p T \alpha$ and $\beta$-actin probes. Exposure times were 3 days for the first TCR $\beta$ panel, overnight for the second TCR $\beta$ and for $\beta$-actin, and 3 weeks for $\mathrm{p} T \alpha$.

of $\mathrm{CD} 3 \varepsilon$ and TCR $\beta$ on immature thymocytes as part of a pre-TCR complex (30).

\section{Dlscussion}

The importance of the CD3 complex for T cell development has been firmly established by experiments using transgenic or knockout mice. Indeed, overexpression of a human $\mathrm{CD} 3 \varepsilon$ transgene in mice inhibits $T$ cell development in a copy number dependent fashion (44) At low copy numbers, T cell development is blocked at the $\mathrm{CD} 44^{\text {to }} \mathrm{CD} 25^{+} \mathrm{DN}$ stage (similar to RAG ${ }^{-1-}$ mice). In contrast, at high copy number, the block is earlier at the CD44hi $C D 25^{-}$stage, raising the possibility that $\mathrm{CD} 3 \varepsilon$ may play a role even earlier in T cell development than either the recombinase genes or TCR $\beta$. However, in $\mathrm{CD} 3 \varepsilon$ deficient mice, T cell development is not arrested until the $\mathrm{CD} 44^{\circ} \mathrm{CD} 25^{+} \mathrm{DN}$ stage (Malissen, personal communication), rather suggesting that this is the first stage where the presence of functional $\mathrm{CD} 3 \varepsilon$ protein is required. This apparent discrepancy could be explained if overexpression of the human $C D 3 \varepsilon$ transgene interfered with development indirectly (e.g. by competing for kinases such as p56 ${ }^{\text {kch }}$ )

In contrast to $\mathrm{CD} 3 \varepsilon_{1}$ T cell development in $\mathrm{CD} 3 \zeta^{+-}$mice $(12-15)$ is arrested later at the DP stage. In addition, when $\mathrm{CD} 3 \zeta$ is overexpressed, development is also blocked at the

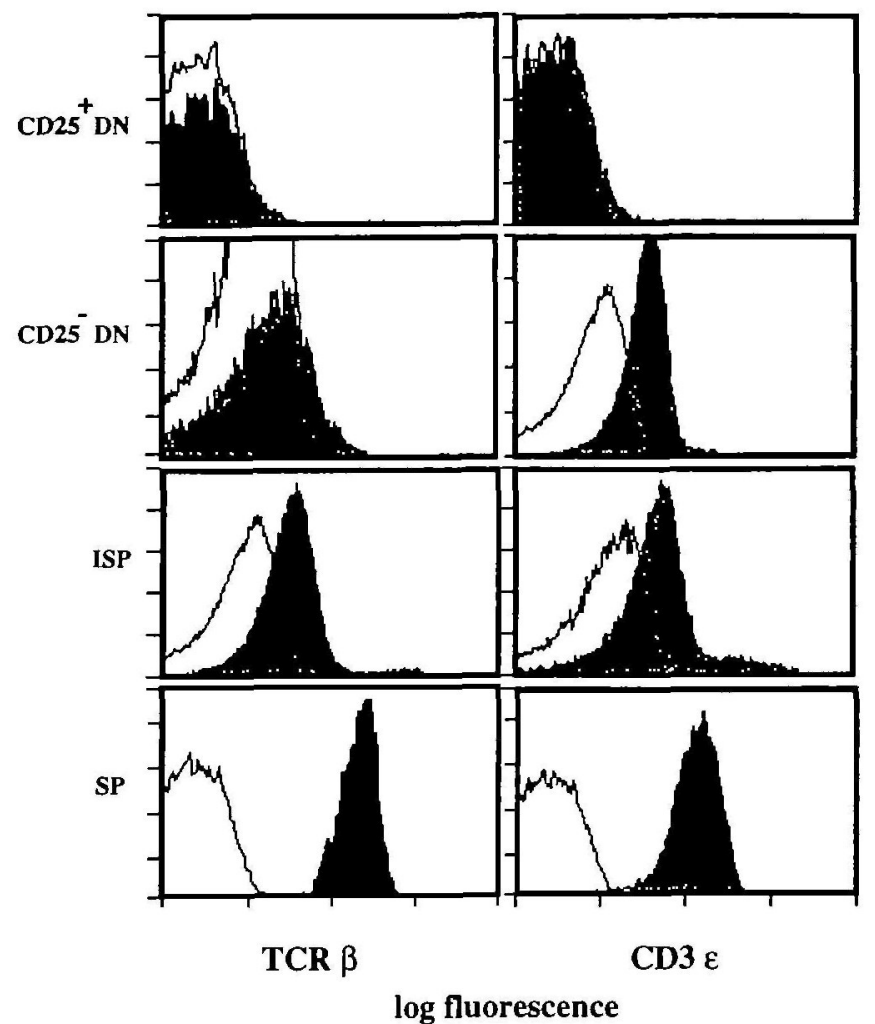

FIg. 3. Surface expression of TCR $\beta$ and CD $\varepsilon$ in immature thymocyte subsets $C D 25^{+} \mathrm{DN}$ and $\mathrm{CD} 25^{-} \mathrm{DN}$ subsets were further gated to be CD44 $4^{\text {lo }}$ and HSA hl ISP and SP correspond to CD4 $4^{-} \mathrm{CD} 8^{+} H S A^{\text {hi }}$ and $\mathrm{CD} 4^{-} \mathrm{CD} 8^{+} \mathrm{HSA} A^{\mathrm{k}}$ subsets respectively Control stanning (indicated by the thin lines) is hamster I $g-P E$

DP stage in a copy-number-dependent manner (45). In this latter study, the authors suggested that the developmental block was due to premature termination of RAG-1 and RAG2 expression preventing productive rearrangements of TCR $\alpha$ and TCR $\beta$ It is of interest that the DP stage of development where the effects of overexpression or absence of $\operatorname{CD} 3 \zeta$ are manifest is correlated with the maximum expression of CD3 $\zeta$ (Fig. 1 and Table 2). These results suggest that while CD3 $\zeta$ is essential for the DP to SP transition (most likely due to its role in signal transduction), it is less important for the earlier DN to DP transition. In the absence of $\mathrm{CD} 3 \zeta$, DP cells are produced but their numbers are decreased compared with normal mice. In addition, the CD44 ${ }^{\circ} \mathrm{CD} 25^{-}$DN subset, which is the immediate precursor of the ISP (pre-DP) subset, and the major cycling DN population in normal mice, is absent in these mice (46). These latter data suggest that $\mathrm{CD} 3 \zeta$ may have a specific role in the control of proliferation of DN thymocytes.

At the mRNA level, CD $44^{\text {to}} \mathrm{CD} 25^{+} \mathrm{DN}$ thymocytes are the most immature subset that expresses all known CD3 components as well as $p$ T $\alpha$ and full length TCR $\beta$. Yet this subset has no easily detectable surface $\mathrm{CD} 3$ or TCR $\beta$ expression. In fact, clear expression of CD3 (measured by anti-CD3 $\varepsilon \mathrm{mAb}$ ) and TCR $\beta$ occur later at the CD25- DN stage. Several explanations for the delayed appearance on 
the surface of expressed CD3 $\varepsilon$ and TCR $\beta$ chains can be entertained. For example, it is possible that limitatıons in posttranscriptional processing or assembly of CD3 or pre-TCR complexes may delay their membrane insertion Alternatively, the pre-TCR complex may (by analogy with pre-B cells) contaln other as yet unidentified components, such as the recently proposed $V$ pre-T (30). In either case it is obvious that the fully assembled (CD3 or pre-TCR) complexes could not be expressed at the cell surface until all components became available.

Finally it is informative to consider our data in the context of other studies of TCR $\alpha \beta$ transgenic mice. Thus we (32) and others (36) have shown that surface TCA $\alpha \beta$ (or CD3) expression in such mice is only apparent at the CD25- DN stage, despite the fact that the TCR $\alpha$ and $\beta$ transgenes are presumably expressed much earlier at the mRNA level. This surprising result, which was obtained independently of the nature of the TCR transgenic construct (cDNA in our case and rearranged genomic DNA in the other), suggests that surface expression of a mature TCR $\alpha \beta-$ CD3 complex is likewise developmentally regulated. It therefore appears that neither the pre-TCR nor the mature TCR $\alpha \beta$ complex can be efficiently expressed on the cell surface prior to the CD25DN stage. To explain this paradox, one could speculate that the CD3 complex exists in two alternate configurations, an early form which is only permissive for CD3 expression (perhaps in association with another unknown molecule) and a later form which can associate with elther the pre-TCR or mature TCR. Such a model would imply that the differential expression of pre-TCR and TCR complexes during development depends upon the regulated expression of $\mathrm{pT} \alpha$ and TCR $\alpha$ genes.

\section{Acknowledgements}

The authors wish to thank Pierre Zaech and Christian Knabenhans for their patient and extremely competent four-color FACS analysis and sorting, and Darryl Reed for help in cloning the $p T \alpha$ probe.

\section{Abbreviatlons}

$\begin{array}{ll}\text { APC } & \text { allophycocyanin } \\ \text { DP } & \text { double positive } \\ \text { DN } & \text { double negative } \\ \text { ISP } & \text { immature single positive } \\ \text { SP } & \text { single positive }\end{array}$

\section{References}

1 Allison, J. P. and Lanier, L. L. 1987 Structure, function, and serology of the T-cell antigen receptor complex Annu. Rev. Immunol. 5:503.

2 Clevers, H., Alarcon, B., Wileman, T and Terhorst, C 1988. The T cell receptor/CD3 complex: a dynamic protein assembly. Annu Rev. Immunol 6.629.

3 Raulet, D H. 1989. The structure, function, and molecular genetics of the $\gamma \delta$ T cell receptor. Annu. Rev Immunol. 7:175

4 Ashwell, J. D. and Klausner, R. D. 1990 Genetic and mutational analysis of the T-cell antigen receptor. Annu. Rev. Immunol. 8:139.

5 Borst, J., Brouns, G. S., de Vries, E., Verschuren, M. C. M. Mason, D. Y and van Dongen, J. J. M. 1993 Antigen receptors on $\mathrm{T}$ and $\mathrm{B}$ lymphocytes: parallels in organization and function.
Immunol Rev. 132:49.

6 Chan, A. C., Desai, D. M and Weiss, A. 1994. The role of protein tyrosine kınases and protern tyrosine phosphatases in $T$ cell antigen receptor signal transduction Annu Rev. Immunol. 12:555.

7 Jorgensen, J. L, Reay, P. A, Ehrich, E. W. and Davis, M M 1992 Molecular components of T-cell recognition Annu. Rev. Immunol. 10:835.

8 Letourneur, F. and Klausner, R. D. 1992. Activation of T cells by a tyrosine kinase activation domaın in the cytoplasmıc tail of CD3 E Science 255:79.

9 Ohashı, P., Mak, T., van den Elsen, P., Yanagı, Y, Yoshikaı, Y, Calman, A., Terhorst, C., Stobo, J. and Weiss, A 1985. Reconstitution of an active surface $T 3 / T$ cell antigen receptor by DNA transfer. Nature 316.606

10 Mombaerts, P, Clarke, A R., Rudnicki, M. A, lacomini, J, Itohara, S., Lafaille, J. J., Wang, L, Ichikawa, Y., Jaenisch, R., Hooper, M L and Tonegawa, S. 1992 Mutations in T-cell antigen receptor genes $\alpha$ and $\beta$ block thymocyte development at different stages. Nature $360 \cdot 225$.

11 Philpott, K. L., Viney, J L., Kay, G, Rastan, S., Gardıner, E M, Chae, S., Hayday, A C and Owen, M J. 1992 Lymphoid development in mice congenitally lacking $T$ cell receptor $\alpha \beta$ expressing cells Science 256:1448.

12 Liu, C.-P., Ueda, R, She, J, Sancho, J., Wang, B., Weddell, G., Loring, J , Kurahara, C., Dudley, E. C , Hayday, A. C , Terhorst, C and Huang, $M 1993$ Abnormal T cell development in CD3- $\zeta^{-1}$ mutant mice and identification of a novel $T$ cell population in the intestıne. EMBO J. $12 \cdot 4863$

13 Love, P E, Shores, E. W, Johnson, M. D., Tremblay, M. L, Lee, E J, Grinberg, A, Huang, S. P., Singer, A. and Westphal, $H$. $1993 \mathrm{~T}$ cell development in mice that lack the $\zeta$ chain of the $T$ cell antigen receptor $S_{C i e n c e} 261.918$

14 Malissen, M, Gillet, A., Rocha, B, Trucy, J, Vivier, E., Boyer, C, Köntgen, F., Brun, N, Mazza, G, Spanopoulou, E, Guy-Grand, $D$. and Malissen, B. 1993 T cell development in mice lacking the

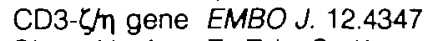

15 Ohne, H, Aoe, T., Takı, S , Kıtamura, D , Ishıda, Y., Rajewsky, K. and Saito, T. 1993 Development and functional impairment of T cells in mice lacking $C D 3 \zeta$ chains. EMBO J 12:4357

16 Levelt, C. N., Carsetti, R and Eichmann, K. 1993 Regulation of thymocyte development through $\mathrm{CD} 3$ II Expression of TCR $\beta$, $\mathrm{CD} 3 \varepsilon$ and maturation to the $\mathrm{CD} 4^{+} \mathrm{CD} 8^{+}$stage are highly correlated in individual thymocytes J. Exp. Med. 178.1867

17 Petrie, H T, Pearse, M, Scollay, R. and Shortman, K 1990 Development of immature thymocytes: initiation of CD3, CD4, and CD8 acquisition parallels down-regulation of the interleukin 2 receptor $\alpha$ chain. Eur J. Immunol. 20.2813.

18 Nikolic-Zugic, J 1991. Phenotypic and functional stages in the intrathymic development of $\alpha \beta$ T cells. Immunol Today 12:65

19 Campana, D., Thompson, J S., Amlot, P Brown, S and Janossy, G 1987 The cytoplasmic expression of CD3 antigens in normal and malignant cells of the $T$ lymphoid lineage. $J$ immunol. 138.648

20 van Dongen, J. J. M., Quertermous, T., Bartram, C R., Gold, D P, Wolvers-Tettero, I. L. M., Comans-Bitter, W. M., Hooıjkaas, H., Adriaansen, H. J., de Klein, A., Raghavachar, A, Ganser, A, Duby, A. D., Seidman, J. G., van den Elsen, P. and Terhorst, C. 1987 T cell receptor-CD3 complex during early $T$ cell differentiation. analysis of immature $T$ cell acute lymphoblastic leukemias (T-ALL) at DNA, RNA and cell membrane level. J. Immunol 138.1260.

21 van Dongon, J. J. M., Krissansen, G. W., Wolvers-Tettero, I. L. M., Comans-Bitter, W M., Adriaansen, H. J., Hooijkaas, $H$., van Wering, E. R. and Terhorst, C 1988. Cytoplasmic expression of the $\mathrm{CD} 3$ antigen as a diagnostic marker for immature T-cell malignancies Blood 71:603.

22 Wiest, D L., Kearse, K. P., Shores, E. W. and Singer, A. 1994. Developmentally regulated expression of CD3 components independent of clonotypic T cell antigen receptor complexes on immature thymocytes J. Exp. Med 180:1375.

23 Groettrup, M., Ungewiss, K, Azogui, O., Palacios, R., Owen, M. J., Hayday, A C. and von Boehmer, H. 1993. A novel disulphidelinked heterodimer on pre-T cells consists of the T cell receptor 
$\beta$ chain and a 33kd glycoprotein Cell 75.283.

24 Jacobs, H., Vandeputte, D, Tolkamp, L, de Vries, E, Borst, J. and Berns, A. 1994. CD3 components at the surface of pro$T$ cells can mediate pre-T cell development in vivo Eur $J$. Immunol. 24934

25 Shinkal, Y. and Alt, F. W. 1994 CD3E-mediated signals rescue the development of $\mathrm{CD} 4^{+} \mathrm{CD} 8^{+}$thymocytes in RAG-2+ mice in the absence of TCR $\beta$ chain expression. Int Immunol. 6.995

26 Levelt, C. N, Mombaerts, P., Iglesias, A., Tonegawa, S. and Eıchmann, K. 1993 Restoration of early thymocyte differentiation in $T$ cell receptor- $\beta$-chain deficient mutant mice by transmembrane signalling. Proc Natl Acad. Sci USA 90.11401.

27 von Boehmer, H. 1990. Developmental biology of T cells in T cell receptor transgenic mice. Annu Rev. Immunol. 8:531.

28 Shinkal, S., Koyasu, S, Nakayama, K., Murphy, K, Loh, D., Reinherz, E. and Alt, F.W. 1993. Restoration of T-cell development in RAG-2 deficient mice by functional TCR transgenes. Science 259:822.

29 Mombaerts, P, Anderson, S. J, Perlmutter, R M., Mak, T W. and Tonegawa, S. 1994 An activated lck transgene promotes thymocyte development in RAG-1 mutant mice. Immunity 1.261.

30 Saint-Ruf, C., Ungewiss, K, Groettrup, M., Bruno, L., Fehling, H $\mathrm{J}$ and von Boehmer, $\mathrm{H} .1994$. Analysis and expression of a cloned pre-T cell receptor gene Scıence 266.1208.

31 Wilson, A, Held, W and MacDonald, H R. 1994. Two waves of recombinase gene expression in developing thymocytes. $J$ Exp Med. 179:1355.

32 Wilson, A., Pircher, H, Ohashi, $P$ and MacDonald, H. R. 1992 Analysis of immature $\left(\mathrm{CD}^{-} \mathrm{CDB}^{-}\right)$thymic subsets in T-cell receptor $\alpha \beta$ transgenic mice Dev. Immunol. 285

33 Wu, L, Scollay, R., Egerton, M., Pearse, M., Spangrude, G J and Shortman, K. 1991. CD4 expressed on earliest T-lıneage precursor cells in the adult murine thymus Nature $349 \cdot 71$.

34 Fowkes, B J and Pardoll, D. M 1989. Molecular and cellular events in T cell development. Adv. Immunol 44.207
35 Pearse, M, Egerton, M, Wilson, A, Shortman, K. and Scollay, R 1989. An early thymocyte development sequence marked by transient expression of the IL-2 receptor. Proc Natl Acad ScI USA. 86.1614.

36 Nikolıc-Zugıc, J, Andjelic, S., Teh, H.-S. and Jain, N 1993. The influence of rearranged $T$ cell receptor $\alpha \beta$ transgenes on early thymocyte development. Eur. J. Immunol. 23:1699.

37 Rothenberg, E. V 1992. The development of functionally responsive T cells. Adv Immunol. 5185

38 Godfrey, D. I. and Zlotnık, A. 1993. Control points in early T-cell development Immunol Today 14.547.

39 Krulsbeek, A. M 1993. Development of $\alpha \beta$ T cells. Curr Opin. Immunol. 5227.

40 Hugo, P. and Petrie, H T 1992 Multiple routes for late intrathymıc precursors to generate $\mathrm{CD} 4^{+} \mathrm{CD} 8^{+}$thymocytes $\mathrm{Adv} \mathrm{Mol} \mathrm{Cell}$ Biol 5.37

41 von Boehmer, H. 1992. Thymic selection a matter of life or death Immunol Today 13.454

42 von Boehmer, H. 1994 Positive selection of lymphocytes. Cell 76.219

43 Nossal, G. J. V. 1994. Negative selection of lymphocytes. Cell 76.229

44 Wang, B., Biron, C , She, J., Higgıns, K, Sunshine, M.-J , Lacy, E Lonberg, $N$ and Terhorst, C 1994 A block in both early $T$ lymphocyte and natural kuller cell development in transgenic mice with high-copy numbers of the human CD3e gene. Proc Natl Acad. SCl. USA 919402

45 Love, P E, Shores, E W., Lee, E. J., Grinberg, A., Munitz, T. I., Westphal, $H$. and Singer, A 1994. Differential effects of $\zeta$ and $\eta$ transgenes on early $\alpha / \beta \mathrm{T}$ cell development $J$ Exp Med $197 \cdot 1485$

46 Crompton, T., Moore, M., MacDonald, H. R and Malissen, B 1994 Double-negative thymocyte subsets in CD3 $\zeta$ chain-deficient mice absence of $\mathrm{HSA}^{+} \mathrm{CD} 44^{-} \mathrm{CD} 25^{-}$cells Eur. J Immunol. 24.1903 